\section{SYMBOLISM IN THE}

\section{CHAOMAE SONG NANG RITUAL $^{1}$}

\section{Panupong Udomsilp ${ }^{2}$ Sukanya Sujachaya ${ }^{3}$}

\begin{abstract}
This paper studies the symbolism of the objects and behaviors in the "Chaomae Song Nang" ritual held in Mueang District, Mukdahan Province, so as to elucidate the meaning of the symbols in relation to the legend of the Chaomae Song Nang as the ancestors of the Mukdahan people.
\end{abstract}

Chaomae Song Nang are the spirits of the daughters of the former ruler of Khanthaburi in Laos. Together with their followers, they are the subject of a ritual held annually in Mukdahan City. It is believed that the Chaomae Song Nang spirits come each year to eliminate the

\footnotetext{
${ }^{1}$ This article is a part of a Ph.D dissertation in Thai Folklore entitled, "Chao Mae Song Nang Spirit Cult in The Mekong Riverine Communities," Department of Thai, Faculty of Arts, Chulalongkorn University. The author would like to thank Chulalongkorn University, "The $90^{\text {th }}$ Anniversary Of Chulalongkorn University Fund" (Ratchadaphiseksomphot Endowment Fund) and Faculty of Arts, Chulalongkorn University for partially supporting this Ph.D. field research..

2 Assistant Professor, Department of Thai and Oriental languages, Faculty of Humanities, Srinakharinwirot University

${ }^{3}$ (corresponding author) Associate Professor, Department of Thai and Director of Folklore Research Center, Faculty of Arts, Chulalongkorn University
}

suffering and troubles of their descendants. This ritual is full of symbolism, which can be observed in the arrangement of the ritual space in the objects that serve as offerings and the placement of said objects, and in the garments and actions of the spirit mediums. Sub-rituals comprising parts of the Chaomae Song Nang ritual are the annual weather forecast, the ritual for the elimination of suffering and troubles, and the floating of bad luck. These sub-rituals are held to bring happiness to the city and to give heart to the spirits' descendants. Consequently, the rituals related to the Chaomae Song Nang have been handed down for generations and persist in contemporary society.

\section{Introduction}

Most people along the banks of the Mekong share belief in the chaopho/เจ้าพ่อ (high-ranking male spirits) and chaomael เจ้าแม่ (high-ranking female spirits). Stories of the chaopho and chaomae are included in the local legends forming the community's migration narratives. People in these communities believe that the chaopho and chaomae, whom they once worshipped, were their rulers or governors, the governor's relatives, or warriors. More importantly, they also believe these spirits were their ancestors, whom they have worshipped since ancient times.

The Chaomae Song Nang/เจ้าแม่สองนาง of Mueang District, Mukdahan Province, are said to be the daughters of the former ruler of Khanthaburi, who migrated from Vientiane. The Mukdahan people believe that the Chaomae Song Nang are ancestors of theirs from the time when Mukdahan City was built and that the spirits are sacred and can protect them and their community from danger. They, therefore, 
perform the Chaomae Song Nang ritual for these spirits annually.

This ritual has been previously studied by Virayut Chaiyaphet (1999) in a thesis entitled "The Traditional Ritual Concerning the Chaomae Song Nang Phi Nong in Mukdahan Province. Virayut's study focuses on five components of the ritual: persons (performers and participants), time, place, associated objects, and process. However, the ritual's symbolism has yet to be analyzed. The relevant symbols are implicit in several parts of the ritual, e.g., the ritual area and the position of the sacred offerings.

Data for the present study were collected on 13-15 May 2008 in Mueang District, Mukdahan Province, through qualitative fieldwork involving participant observation of the ritual and interviews with the ritual practitioners and the people of Mukdahan City.

This paper aims to study the meaning of both symbolic objects and symbolic behaviors in the Chaomae Song Nang ritual using Victor Turner's concepts of symbolic objects and symbolic behaviors as an analytical framework (Turner 1967: 46, cited in Pichet Saiphan 1996: 12-14).

\section{Definition of terms}

The Chaomae Song Nang are said to be the spirits of two daughters of a ruler who was a warrior in the Kingdom of Lanchang. The villagers of Mukdahan Province consider these spirits to be significant and sacred and to be able to protect them and their community from danger.

A chaopho is an ancestral spirit who was a king, governor, or warrior in the past. The villagers revere these spirits and believe they are sacred and can protect the villagers and their society from danger.

A nang thiam/นางเทียม is a woman (or man) who is chosen by a particular chaopho or chaomae as a medium whom the spirits possess in order to communicate with humans. Regardless of whether a nang thiam accepts wholeheartedly or is unwilling to serve as a medium, they will become a complete medium after receiving the khan $h a$ /ขันห้า 'the offering bowl.'

The cham/จ้ำ is the person who guards the Chaomae Song Nang shrine and arranges the shrine and offerings for the individual or communal rituals. He or she is the one who talks to the medium about the problems of the villagers or community and asks for solutions. The cham can be a man or a woman and is chosen by the chaomae from a member of the family of the former cham or nang thiam. If there is no nang thiam in the Chaomae Song Nang shrine, the cham himself or herself can lead the villagers in performing the ritual.

The nang piang/นางเปียง are women who are obliged to guard the Chaomae Song Nang shrine and to serve as mediums during the ritual. The chaomae will choose two nang piang, a left one and a right one, from members of the same family of the former nang thiam.

\section{The background of the Chaomae Song Nang ritual}

According to local history, Mukdahan City had been abandoned for a long time before Chao Chanthakinnari, the ruler of Ban Luang Phon Sim, Khanthaburi City, discovered that the area around Mukdahan was more fertile than that on the left bank 
of the Mekong River. Thus, he moved his people to settle there during the Dhonburi period (Surachit Chantharasakha n.d.: 7). The Mukdahan people believe that these people were the first group to settle in this area. The Chaomae Song Nang, who had migrated because of warfare and built a new city called Khanthaburi, are also believed to be their ancestors.

According to legend, the Chaomae Song Nang, named Nang Phim and Nang Pha, were daughters of the ruler of Vientiane. They and their people migrated southward to build a new city. During the Suang Ruea/ส่วงเรือ, boat competition festival, Nang Phim and Nang Pha were traveling by boat. Unfortunately, their boat capsized at the mouth of the Muk River, and they drowned. Later, on the eleventh day of the waxing moon of the sixth lunar month, someone heard women crying near the mouth of the Muk River. Through a spirit medium, people learned that the women they had heard crying were the spirits of the Chaomae Song Nang. Consequently, a shrine was built at the mouth of the Muk River and the spirits were invited to reside in the shrine from that time on (Virayut Chaiyaphet 1999: 52).

The Chaomae Song Nang have been the city's sacred spirits since then. When their former shrine was destroyed by the river's current, a new one was built on the shore of the Mekong in front of Sri Mongkhon Thai Temple. Villagers believe that the two spirits are their ancestors and that they are sacred and can protect them and their society from harm. Therefore, they have held the Chaomae Song Nang ritual annually on the eleventh day of the waxing moon of the sixth lunar month.

\section{Ritual practitioners and participants}

Ritual practitioners consist of one spirit medium for the Chaomae Song Nang, two spirit mediums for the chaopho and chaomae's followers, one cham and two nang piang (the servants of the Chaomae Song Nang). The participants are of various ethnic groups in Mukdahan City: Thai, Chinese-Thai, Vietnamese-Thai, Laotian, Phuthai, and Kha.

\section{The stages of the ritual}

The Chaomae Song Nang ritual proceeds in five stages, as follows.

\section{The preparation of the offering}

The spirit mediums, the servants, and their relatives and disciples help one another in preparing two sets of sacred offerings for presentation to the Chaomae Song Nang and the Chaopho Fa Mung Mueang, the former mahesak, a term used to refer to the guardian spirit of Mukdahan City. The offerings, newly made for this special occasion, are prepared on the tenth day of the waxing moon of the sixth lunar month, which was May 14 in 2008. They consist of several candles, a pair of boiled chickens, liquor, prepared betel, cigarettes, dessert, fruit, sweet drinks, a footed baisri tray, garlands, and fragrant flowers. It is remarkable that there is no boiled chicken in the offering set for Chaomae Song Nang because villagers believe the Chaomae Song Nang are deities. These offerings are prepared in the morning before starting the ritual. Preparation before that time is prohibited because it is believed that Laotian ghosts will otherwise come to eat and possess someone. 


\section{The ritual space for humans and objects}

It is the duty of the cham's relatives and disciples and of the mediums to arrange the ritual area. The cham erects a tent on the cement ground and stretches a rope across to divide the space into inner and outer areas. The inner area is where the spirit mediums perform the ritual. The outer area is where their disciples wait to present offerings to the spirits.

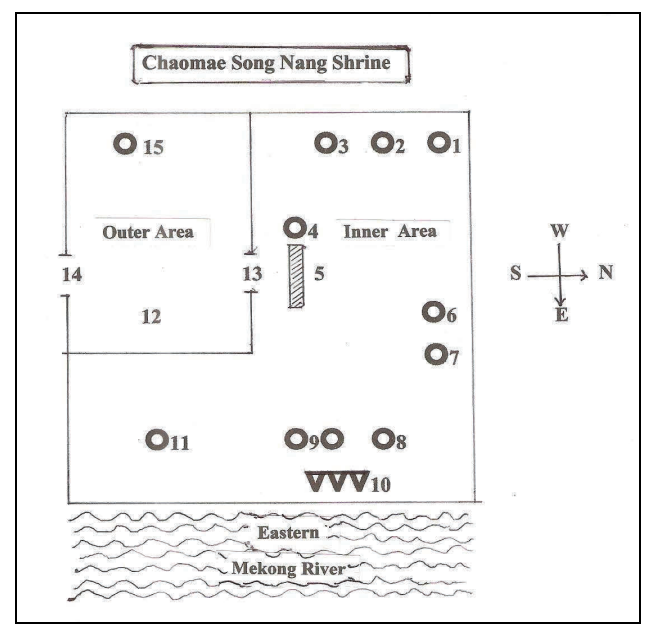

Figure 1: The ritual area

The ritual space is set up in front of the Chaomae Song Nang shrine. Its several positions can be categorized into two groups (see Figure:1).

\section{The first group consists of positions for spirit mediums and participants:}

1. the spirit medium of the Chaomae Song Nang and Chaopho Fa Mung Mueang;

2. the spirit medium of the followers of the Chaomae Song Nang, i.e., Chaopho Ratchawongsuek, Chao Kromhua, and Luang Wicha;

3. the spirit medium of another group of the Chaomae Song Nang's followers, i.e., Chaopho Khamdaeng, Chaomae
Khamlueang, and Chaopho Huadon (naga);

6. the drum and gong musicians;

7. the elderly and descendants of the ancient governor; and

12. the disciples and people waiting to worship their reverential spirits and make a wish.

The second group comprises the positions for ritual objects:

4. a large water jar holding water from the Mekong River;

5. an ancient weapon stand consisting of lances, swords, spears, guns, and crossbows; 8 and 9. offerings for Chaopho Fa Mung Mueang and the Chaomae Song Nang; 10. the Krathong Loi Kroh,(banana stalk used for floating misfortune); 11. a tub of water prepared for the naga to enjoy playing in;

13 and 14. the inner and outer doors, respectively; and

15. the pot of joss sticks and candles.

\section{The performance of the Chaomae Song} Nang ritual

The performance runs in the following phases. Firstly, the spirit mediums go to Chaopho Fa Mung Mueang's shrine to invite him to participate in the ritual at the Chaomae Song Nang's shrine. Secondly, the cham checks the perfection and correctness of the offerings. Lastly, the spirit mediums undergo possession four times. 


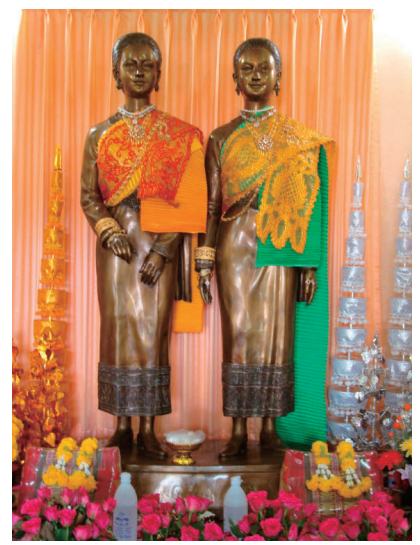

Figure 2: Chaomae Song Nang Sculpture

\section{The first possession ritual: summoning Chaopho Fa Mung Mueang, the old city guardian spirit and his followers to participate in the ritual}

At the start, the three spirit mediums raise the offering bowls and make a solemn wish that the chaopho possess them. While they are making this wish, the drummers and gong players loudly beat the drums and gongs faster and faster. Chaopho $\mathrm{Fa}$ Mung Mueang, Chaopho Ratchawongsuek, and Chaopho Khamdaeng are invited to possess the mediums.

In 2008, Chaopho Fa Mung Mueang was believed to possess the spirit medium Ms. Sudsakhorn Sawatwongchai. ${ }^{4}$ When possessed, she donned red garments, stood up, and raised her hands. Her character was strong, and her face was plain. She danced and walked to re-check the offerings. While she was doing this, the cham made a gesture of respect by pressing the palms of his hands together at

\footnotetext{
${ }^{4}$ Interview, Sudsakhorn Sawatwongchai, $14^{\text {th }}$
} May 2008. the chest responding to the orders or advice of the spirits. After re-checking the offerings, Ms. Sudsakhorn walked to bless her disciples and received the offerings.

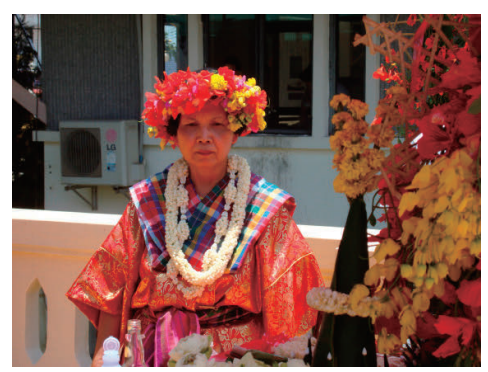

Figure 3: The spirit medium of Chaopho Fa Mung Mueang

Chaopho Ratchawongsuek was believed to possess Ms. Doklam Charutan. When she was possessed, she donned red garments, stood up, and jumped strongly with joy. This character belonged to a spirit who had been a soldier of the Chaomae Song Nang.

Chaopho Khamdaeng was believed to possess Ms. Phensopha Phrommueang. When she was possessed, she donned red garments, stood up, jumped energetically with joy, made a noise, and danced actively. This character belonged to another soldier spirit. ${ }^{5}$

All of the spirit mediums danced facing the offering table. While they were dancing, they pointed their fingers to the offerings signifying that the chaopho had already received or eaten the offerings. Then, all of the spirit mediums danced to their crowded disciples who had been waiting to present the offerings and to receive blessings. Some disciples presented a bottle of liquor to the spirit mediums.

\footnotetext{
${ }^{5}$ Interview, Phensopha Phrommueang, $15^{\text {th }}$ May 2008.
} 
After taking one drink, she returned the bottle to the owner; sometimes she might order the cham to place it on the table. Some disciples presented fragrant garlands, which the spirit mediums smelled and returned to the owner. Some presented scented water or perfume, which the spirit mediums sprayed on the owners to enhance their auspiciousness. The spirit mediums spent about forty minutes receiving offerings from their first group of disciples. Then they returned to their seats, raised their offering bowls, and prayed for the chaopho to dispossess them.

\section{The second possession ritual:} summoning the elder of the Chaomae Song Nang and her followers

The three spirit mediums stood by as they had done for the first possession ritual, inviting other chaomae and chaopho to possess them.

The elder Chaomae Song Nang, Nang Phim, was believed to possess Ms. Sudsakhorn Sawatwongchai. When possessed, the medium chose silk garments and put on accessories such as a golden bracelet and a diamond ring indicating her high status. Later, she danced gracefully and walked politely, signifying her noble bearing as the governor's daughter.

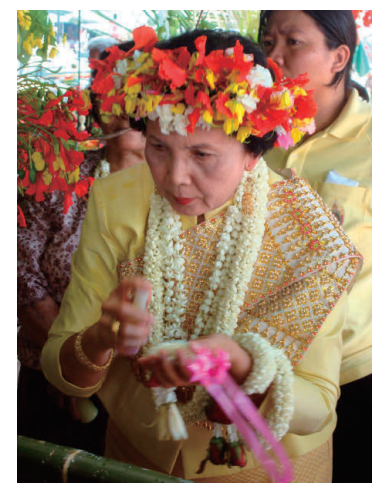

Figure 4: The spirit medium of Nang Phim
Chao Kromhua was believed to possess Ms. Doklam Charutan. When possessed, she once again chose red garments. She acted strongly and seriously like a soldier.

Chaomae Khamlueang, a sister of Chaopho Khamdaeng, with whom she had emigrated from Vientiane, was believed to possess Ms. Phensopha Phrommueang. She dressed in yellowish garments and then joined Chaomae Phim and Chaopho Kromhua.

The spirit mediums danced in the inner area. Then, they came to receive offerings, such as liquor, scented water, perfume, and fragrant garlands from a new group of disciples. These people, who were Thai, Chinese-Thai, Vietnamese-Thai, Phuthai, Kha, and Laotians, arrived a few at a time all day. Some disciples presented the offerings to both the chaomae and chaopho. Some made offerings only to the Chaomae Song Nang or only to the chaopho and chaomae from their own village shrines. Once the disciples had presented the offerings, the spirit mediums walked to their own seats to invite the spirits to dispossess them. Then they took a rest and talked normally to general people.

\section{The third possession ritual: summoning the younger of the Chaomae Song Nang and her followers}

The third possession ritual was like the two previously described. When the mediums were ready, the drummers and gong players beat their drums and gongs faster and faster, signaling to the chaomae and chaopho that the sacrifice was starting and also inviting them to possess the spirit mediums.

The younger of the Chaomae Song Nang, Nang Lomphama or Nang Pha, was believed to possess Ms. Sudsakhorn Sawatwongchai. 
When possessed, the medium chose silk garments. The spirit medium then danced gracefully with only the right hand, laying her left arm beside her waist. The villagers said that this happened because Nang Pha's left arm had been broken in a boat accident; thus she could not raise her broken arm when she danced.

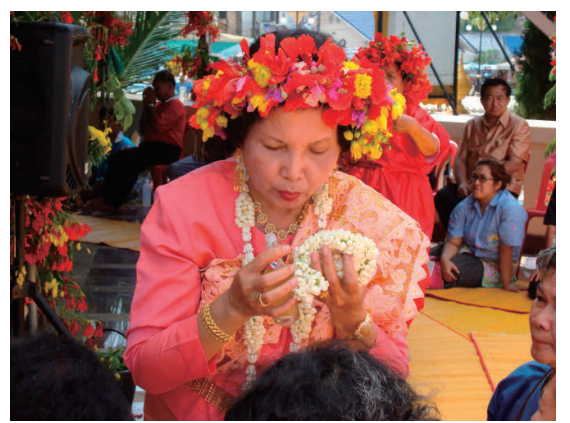

Figure 5: The spirit medium of Nang Pha

Luang Wicha was believed to possess Ms. Doklam Charutan. When possessed, she put on red garments. She then danced like Chaopho Ratchawongsuek and Chao Kromhua; that is, she raised her hands up strongly and seriously, because the spirit had been a soldier.

Chaopho Huadon (naga) was believed to have possessed Ms. Phensopha Phrommueang. When she was possessed, she put on red garments and wore a traditional sash around her shoulders. Chaopho Huadon was cheerful. When the medium danced, she also jumped up and down happily and made a joyful noise, entertaining all the disciples, crawled on the floor, and played in the water in the tub.

The third possession ritual progressed much like the first two. When the spirit mediums blessed their disciples and received the offerings, they did not smile or talk but only maintained plain faces.
Therefore, the atmosphere took on a serious and sacred cast. The disciples showed respect for and stood in awe of the spirits, except when Chaopho Huadon made a noise like a monkey's voice, which caused the atmosphere to become less serious and added a little relaxation and fun.

\section{The last possession ritual: the prophecy}

The last possession ritual started at 3 p.m. When the time came, the spirit mediums performed as usual.

Chaopho Fa Mung Mueang, who had been the old city guardian spirit and the Mukdahan City pillar spirit since the founding of the city, was believed to possess Ms. Sudsakhorn Sawatwongchai again. This spirit chose red garments. Luang Wicha was believed to possess Ms. Doklam Charutan again. Chaopho Huadon was believed to possess Ms. Phensopha Phrommueang again.

In this last possession ritual, the spirit mediums went out from the ritual space to perform the weather forecast ritual, the ritual of surveying the quantities of rain and water in the Mekong River. They then prophesied the precipitation and the amount of water in the Mekong River in the following year. The prophecy also included good harvest and prosperity of the community. This was to give assurance to their disciples, whose main income derives from agricultural produce.

\section{The floating of misfortune ritual}

After the weather forecast ritual, the spirit mediums of Chaopho Fa Mung Mueang and Luang Wicha each took two swords from the weapon stand, while the spirit medium of Chaopho Huadon took a 
crossbow. The cham then attached a candle on the top of each sword and the crossbow. While the mediums performed a dance with the weapons, the cham lit the candles and kept them illuminated throughout the performance. This dance is called Ram Boek Dab/รำเบิกดาบ. Chaopho Fa Mung Mueang's spirit medium danced up to three receptacles and lit the joss sticks and candles in the receptacles with the fire from the candle on the top of her sword, as did the spirit mediums of Luang Wicha and Chaopho Huadon. Then, the receptacles were carried to and placed in the Mekong River to eliminate bad luck. Later, the spirit medium of Chaopho $\mathrm{Fa}$ Mung Mueang came to sprinkle holy water on the crowded disciples. After that, the mediums went to greet the older relatives of their families before returning to their seats to invite the spirits to dispossess them.

\section{Inviting ancestral spirits to return to their spirit land}

After returning to their seats, the spirit mediums raised the offering bowls and prayed for the spirits to return to their spirit land. Then they announced the official end of the annual ritual, which occurred around 4 p.m.

\section{Analysis of the symbols in the ritual}

The Chaomae Song Nang ritual has been sacred in and vital to the lives of the Mukdahan people, who are tied to traditional beliefs and ancestral spirit worship. The offerings have to be prepared in accordance with traditional patterns, because these objects are considered indispensable components of the ritual. The actions of the spirit mediums and the others during the ritual performance reflect the interesting and meaningful worldviews of the Mukdahan people.

Now, I will analyze the meanings of the symbols in the ritual and try to describe how the ritual space, the symbolic objects, and the behaviors of the spirit mediums and their disciples reflect the sacredness of the ritual and the ancestral beliefs which have been handed down to the Mukdahan people of today.

\section{The ritual space in relation to humans and objects}

The ritual space is prepared for the performance of the ritual only on the eleventh day of the waxing moon of the sixth lunar month. This day is specifically mentioned in the Chaomae Song Nang legend. The cham and the spirit mediums' disciples will transform a profane space into a sacred one, using rope to divide the space into two areas. The inner area is specifically reserved for the spirit mediums. They use this area for summoning the spirits for the possession rituals. All other people are prohibited from entering this space except for older members of the spirit mediums' families and other very important persons, such as the current Mukdahan governor or local governmental representatives.

The inner area is where the ancient weapon stand holding the sacred weapons to keep evil spirits away is set up. It is placed in front of the inner door before the entrance to the area of possession ritual. Moreover, chaleow 'five-pointed plaited bamboo,' another set of defenses against evil spirits, are attached around the outside of the ritual area. The possession area is to the west which is believed to be the same direction of the dead and in front of the Chaomae Song Nang shrine and its front 
faces the Chaopho Fa Mung Mueang shrine. This direction is believed to be the direction of the dead. The positions of the spirit mediums' seats are fixed depending on their respective ranks and social statuses. The seat of the Chaomae Song Nang and Chaopho Fa Mung Mueang's spirit is placed farthest to the north as the ritual president. Other chaopho and chaomae sit to the south of the president. They are the spirit medium of Chaopho Ratchawongsuek, Chao Kromhua, and Luang Wicha and the spirit medium of Chaopho Khamdaeng, Chaomae Khamluang, and Chaopho Huadon. The offering space is in an open area to the east. This is the direction in which Ban Luang Phon Sim, Khanthaburi City, lies, the city of the Mukdahan people's ancestors before they moved to their present location. The offering area to the east on the Mekong shore is for presentation to the naga. According to the legend "Pu Chao Thani built Lanchang Kingdom," the naga was not a snake, but a phraya or ruler of many regions and cities (Humphan Rattanawong 1994: 106). Moreover, the residents of Mukdahan believe setting the offerings in the open area is essential to celestial spirit worship.

The outer area, separated from the inner area by the rope, is still in the ritual space. It is decorated with chaleow to protect against evil spirits and is reserved for the spirit mediums' disciples. Most of them fear the power of the Chaomae Song Nang. They do not dare to show disrespect during the performance of this solemn ritual.

\section{Symbolism of the objects used in the ritual}

Many symbolic objects are used in the ritual. They are as follow. The Khrueang khai/เครื่องคาย are a set of offerings consisting of a bowl of rice topped with two eggs, two sets of one trident-shaped candle tied to thirty-two straight candles, a chaleow, six baht worth of coins, a pair of betel nuts and cigarettes (see Figure: 6 ). The khrueang khai represent symbolic offerings used as communication devices to summon the Chaomae Song Nang to come to the ritual.

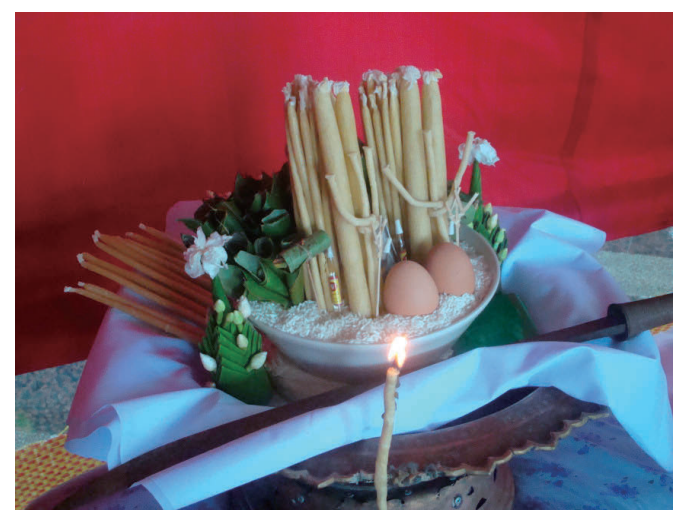

Figure 6: the Khrueang khai

The thirty-two straight candles symbolize a human's thirty-two organs. The tridentshaped candle represents a sacred weapon; the chaleow, a protective device. The whole set of thirty-two straight candles, trident shaped candle, and chaleow together signify that the whole community will be protected by the sacred weapon and the sacred chaleow; thus, the people will be safe and healthy and be guarded against all dangers and diseases.

In other rituals raw eggs may signify fertility; however, in this ritual, they represent protection and care. Ratchanee Suriyachaiwat explained that eggs are symbols of protection and care, as if a hen (ancestral spirits) were taking care of her own chickens (disciples, followers, and villagers). ${ }^{6}$ Thus, in the Chaomae Song Nang ritual, the eggs symbolize the

\footnotetext{
${ }^{6}$ Interview, Ratchanee Suriyachaiwat, $15^{\text {th }}$ May 2008
} 
Chaomae Song Nang and other ancestral spirits taking care of the people of Mukdahan City and protecting them from all trouble and disease.

The rice is an auspicious object in the ritual. Ms. Orawan Chuahan said that the rice was sacred and used against evil spirits. As rice is auspicious, when the ritual ends, the spirit mediums, the servants, and their descendants will take portions of the rice home in order to scatter it around their houses to ward off all evil spirits. ${ }^{7}$

The khan ha/ขันห้า and khan paet/ขันแปด are offering bowls used by the spirit mediums in summoning the Chaomae Song Nang and the chaopho to the ritual. The two offering bowls are symbols of the religious precepts of the spirit mediums. Generally, all of the spirit mediums follow the same taboos and obligations regarding maintenance of the five and eight precepts, e.g., abstaining from eating meat such as cow or buffalo meat, from having meals at funerals, and from having sexual relations with their husbands on Buddhist sabbath days. If they follow these precepts, the obligations will help purify their minds and to be ready for being possessed by the spirits.

The garments of the Chaomae Song Nang represent the Chaomae Song Nang herself. They are made of silk, consisting of a close fitting blouse with long round sleeves and a traditional tube skirt. The blouse and skirt are of the same color. Each of the Chaomae Song Nang chooses her own garments. Their garments are noticeably different from the garments of the other chaopho and chaomae. They are fine and expensive. Moreover, the spirit

${ }^{7}$ Interview, Orawan Chuahan, $11^{\text {th }}$ May 2008 medium of the Chaomae Song Nang wear diamond-studded golden earrings, a diamond-studded golden necklace, and golden bracelets. Other accessories made of gold and diamonds are carefully stored in a purse by the servants. These accessories indicate the status of the Chaomae Song Nang, who as daughters of the ruler of Khanthaburi, were highranking ladies. At the same time, the spirit medium is a descendant of the wealthy prior governor of Mukdahan; thus, the fabulous accessories for the spirits also indicate the status of the spirit medium.

The garments of Chaopho Fa Mung Mueang represent this particular chaopho. According to the legend, this spirit was the son of a Mukdahan governor. He was also a warrior and had been the guardian spirit of Mukdahan City. His garments are red with an ancient golden decorative design, the symbol of the descendant of Mukdahan's ruler.

The garments of the other chaopho, Chaopho Ratchawongsuek, Chao Kromhua, Luang Wicha, and Chaopho Khamdaeng are red shirts, a pair of red trousers, traditional sashes tied around the waists, and red turbans. These garments symbolize ancient soldiers.

A large water jar filled with water from the Mekong River symbolizes fertility and purity. 


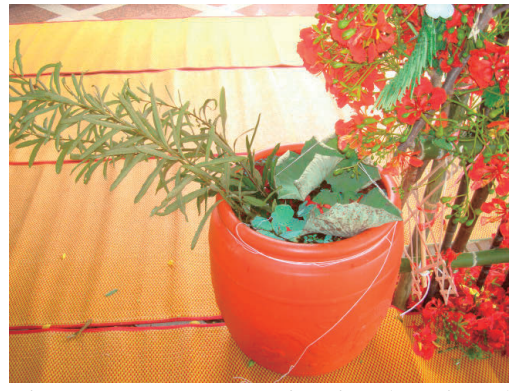

Figure 7: A water jar in the ritual

The tub in the ritual symbolizes the Mekong River. It is prepared for Chaopho Huadon. Since he is a naga, he may want to play with the water while the ritual is being performed. The tub is actually filled with water from the Mekong River and represents the river.

The three sets of food offerings go to the three main spirits in the ritual. Two sets are for the Chaomae Song Nang, and the other set is for Chaopho Fa Mung Mueang. The first two sets consist of sweets, fruit, water, sweet water, and betel nuts. The offering set for chaopho contains tobacco, liquor, and a pair of boiled chicken. The chickens' beaks are pulled out and made use of during the fertility prophecy. The offerings are prepared in plentiful amounts since large quantities signify a large quantity of rain and abundance of food in the coming year.

The boxes made of banana stalks used for floating misfortune are objects for dispelling bad luck. Inside the receptacles, there are three-colored sticky rice and food offerings for the spirits from Laos and water spirits who would come to take away the inauspiciousness and bad elements from the community. Before putting the rice into the receptacles, the spirit mediums with their relatives and disciples take some three-colored sticky rice and touch their bodies with it so as to remove inauspiciousness, bad luck, and diseases from their bodies symbolically. ${ }^{8}$

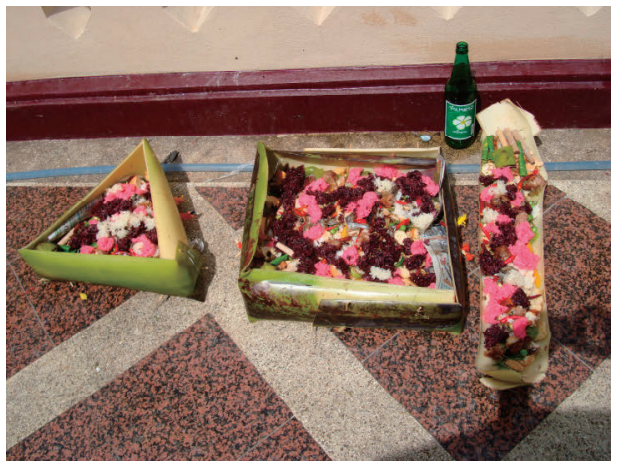

Figure 8: The boxes made of banana stalks used for floating misfortune

Liquor, scented water, and fragrant garlands are presented by the disciples to the Chaomae Song Nang and their chaopho followers. The liquor left in the bottles, after being drunk by the chaopho, is the symbol of auspiciousness and will therefore be taken home by the participants to increase the auspiciousness of their and their family members' futures. The scented water inhaled by the Chaomae Song Nang and sprayed on their disciples and the fragrant garlands smelt by the chaomae and worn around the necks of their disciples causing their disciples' skin to have a pleasant aroma also symbolize auspiciousness.

\section{Symbolism of the behaviors and actions in the ritual}

Dancing forms a major part of the Chaomae Song Nang ritual. Each of the spirit mediums and chaopho acts and dances differently from the others. When the spirit mediums perform the dancing

\footnotetext{
${ }^{8}$ Interview, Praphat Sawatwongchai, $15^{\text {th }}$ May 2008
} 
style of their spirits, the participants recognize that the spirits have possessed the spirit mediums, and they can also identify who is the elder or the younger of the Chaomae Song Nang. The elder walks beautifully and traditionally and dances slowly signifying that the spirit was a high-ranking lady of royal blood. The younger walks and dances like her elder sister but bends her left arm as mentioned above. ' Chaopho Fa Mung Mueang, Chaopho Ratchawongsuek, Chao Kromhua, Luang Wicha, and Chaopho Khamdaeng dance seriously, actively, and robustly, symbolizing ancient warriors. Chaomae Khamlueang, who is believed to have been Chaopho Khamdaeng's younger sister, dances actively and joyfully like an ordinary woman. Chaopho Huadon, the naga in the middle of the Mekong River, dances and jumps around cheerfully. In previous years, this spirit's mediums had lain down, crawled on the floor and played joyfully in the water in the tub implying that they were the naga.

The traditional dance is performed periodically throughout the day in order to give a chance for numerous disciples to come into close contact with the mystical powers. During the ritual time, the disciples and the other Mukdahan people sit and watch politely, in awe of the sacred power in their particular area. No one would dare to intrude on the inner area or to behave disparagingly or disrespectfully. The prohibitions which the Mukdahan people have followed for a long time also include abstention from fishing, playing in the water, or taking baths in the Mekong River on the ritual day. It is said that, if

\footnotetext{
${ }^{9}$ Interview, Somrak Wongwathana, $15^{\text {th }}$ May
} 2008. one were to break these prohibitions, it would cause him or her to die.

Receiving objects from the disciples is another component of the ritual. In receiving liquor, the chaomae and chaopho take one drink and then return it to the disciples. If the spirit is satisfied, the cham orders the liquor bottle to be placed on the offering table. After the ritual, the disciples can take it back to their homes and keep it to increase the auspiciousness of their and their family members' futures. When the chaomae and chaopho receive scented water, they inhale its fragance, spray some on their disciples, and then return the water to the people who have brought it. When offered fragrant garlands, the spirit mediums smell them and then return them to the owners. The disciples take the scented water and fragrant garlands home because the fragrant smell is another symbol of auspiciousness which remains with them and brings happiness to their families.

The weather forecast ritual is performed during the fourth possession ritual. During this ritual, Chaopho Fa Mung Mueang dances to the outside area, looks up, and points his index finger first to the sky and then to the Mekong River. Then, the cham enquires about the rain fall and the water level in the Mekong River during the coming year and asks whether the upcoming rainy season will supply them with sufficient amount of water for a good harvest, or whether the villagers and the province will be happy. In the ritual held on May 15, 2008, the spirit medium answered that the rain in the coming year would be sufficient and the villagers and the province would be happy. 


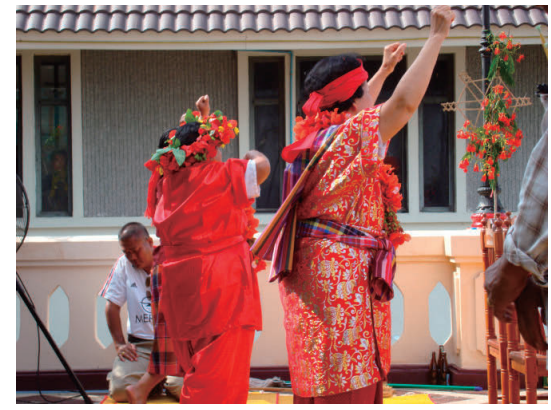

Figure 9: The weather forecast ritual

The actions of the spirit medium and the cham are symbolize the prophecy related to fertility. The villagers who join in the ritual wait eagerly to hear the prophecy, which can influence their future. The prophecy encourages them in their life and work and also assures them that agricultural production will be as good as they hope.

The ram boek dab or sword dance, is performed after the weather forecast ritual. When the weather forecast ritual is finished, Chaopho Fa Mung Mueang and Luang Wicha take up two swords and dance, while Chaopho Huadon takes a crossbow and dances. The cham quickly attaches candles to the top of the swords and crossbow. Later, the three chaopho dance and twirl their weapons around their bodies and heads as symbols of the elimination of inauspicious elements and diseases. The swords, as sharp weapons, symbolize the destruction and dispelling of all inauspiciousness from the people and the province. The candles at the top of the weapons symbolize the light clearing the way to a new day, a new year, and a new world without dangers.

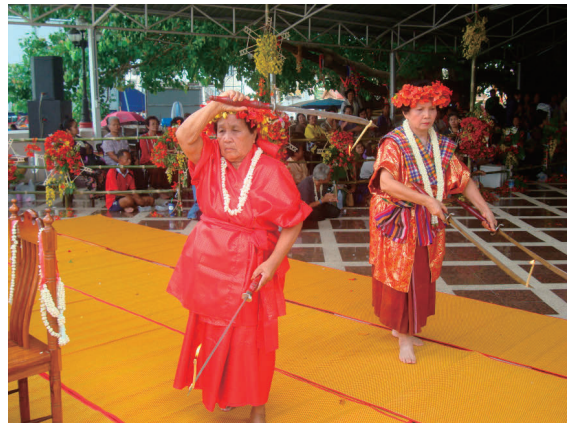

Figure 10: The ram boek dab, 'sword dance'

The floating of misfortune forms the penultimate portion of the annual Chaomae Song Nang ritual. The spirit mediums and their disciples cut their fingernails and pluck out some of their hair, then put these things into the three receptacles. This is supposed to get rid of bad luck. Moreover, they take threecolored sticky rice, which they have touched their bodies with, and place it into the receptacles, offering it to the ghosts that are believed to bring inauspiciousness and bad elements to them and their society.

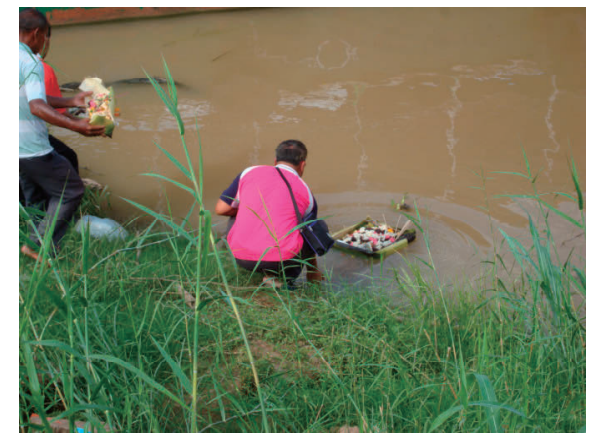

Figure 11: The floating of misfortune

Before floating the receptacles, the three chaopho light the joss sticks and candles in the receptacles, signifying the removal of bad luck into the receptacles which are then taken to the Mekong River to be floated away. It is believed that the bad luck then washes out and that the spirits from Laos and water spirits come to take the offerings in the receptacles. The 
floating of misfortune is a symbol of the elimination of bad luck from the people and their province and of the bringing happiness and peace to them and their society in the future.

Inviting the ancestral spirits to return to the spirit land constitutes the final stage of the ritual. When the spirit mediums have return to their seats, they raise the offering bowls and pray for the spirits to return to the spirit land. Later, they take their turbans off, stroke their heads three times, and formally announce the end of the annual ritual the shrine. That is how they invite the ancestral spirits to return to their spirit land.

The ritual lasts for the entire day. The possession ritual period is most serious. All of the spirit mediums perform the ritual strictly. The disciples wait in awe to present their offerings to their spirits. Generally, the ritual area is a profane area where people normally come to worship the Chaomae Song Nang. However, when the ritual time arrives, this area is turned into a sacred space full of obligations and prohibitions. The persons in the sacred space are the spirit mediums, the servants, the cham, the spirit medium's older relatives and disciples, and the Mukdahan people. These people follow the traditional ritual patterns until they are completed. The spirit mediums perfectly oblige as the spirit mediums of the Chaomae Song Nang and the chaopho followers. The disciples and other people, who come to be given blessings and auspiciousness, generally feel happy and satisfied, as they had expected and desired. Once the ritual is over, the sacred area returns to being profane again. All of the performers and participants return to their normal lives and live their lives as usual.

\section{Conclusion}

Study of the meanings of the symbols in the Chaomae Song Nang ritual help us understand the ideas and beliefs of the people of Mukdahan relating to the Chaomae Song Nang legend. Since the ancestors of the Mukdahan people immigrated from Ban Luang Phon Sim, Khanthaburi City, Laos, and settled down in Mukdahan, the Chaomae Song Nang ritual represents an important occasion for the Mukdahan people to congregate and remind themselves of their Laotian ancestry.

The objects and behaviors of the Chaomae Song Nang ritual symbolize the participants' being the descendants and the retinue of the rulers of their former city. The people believe that, if they perform the ritual in a satisfying manner, their ancestral spirits will protect them and their belongings from evil and bless them with prosperity. In addition, these symbols also reveal something of the way of life of the local people, which is related to agriculture. All the symbols in the forecasting ritual and the floating of misfortune reflect the Mukdahan people's wishes for fertility and security in their lives.

\section{References}

Humphan Rattanawong. 1994. Naga and the Beliefs of Laotians (นาค(นาคะ)และความ เชื่อของชนชาติลาว), paraphrased by Wannasakphichit Boonserm. Srinakharinwirot University Maha Sarakham Campus 12 (July December 1994): $98-111$.

Pichet Saiphan. 1996. Naga Cultural Symbol of Northeastern Thailand: a Study in Symbolism, Ritual and Social Process, (“นาคาคติ” อีสานลุ่มน้ำโขง: ชีวิตทาง 
วัฒนธรรมจากพิธีกรรมร่วมสมัย). Master's

Thesis, Department of Anthropology, Faculty of Sociology, Thammasat University. (In Thai)

Surachit Chantharasakha. n.d. Mukdahan Province in the Past (จังหวัดมุกดาหารในอดีต). Mukdahan: Information Center Isan Culture and Art Research Institute. (In Thai)

Turner, Victor W. 1967. The Forest of Symbo: Aspects of Ndembu Ritual. Ithaca: Cornell University Press.

Virayut Chaiyaphet. 1999. The Traditional Ritual Concerning Chao Mae Song Nang Phi Nong in Mukdahan Province. (ประเพณีพิธีกรรมเกี่ยวกับเจ้าแม่สองนางพี่น้องจังหวัด มุกดาหาร). Master's Thesis. Department of Thai Studies (Social Science), Mahasarakham University. (In Thai) 